\title{
Revisão / Review \\ DEGRADATION OF CAFFEINE BY MICROORGANISMS AND POTENTIAL USE OF DECAFFEINATED COFFEE HUSK AND PULP IN ANIMAL FEEDING
}

\author{
Paulo Mazzafera \\ Depto. Fisiologia Vegetal - Instituto de Biologia / UNICAMP, C.P. 6109 - CEP: 13083-970 - Campinas, SP. \\ Corresponding Author <pmazza@obelix.unicamp.br>
}

\begin{abstract}
Coffee husk and coffee pulp are coffee processing by-products. Coffee husk is obtained when harvested coffee is processed by the dry method, and coffee pulp is produced by the wet method. In Brazil, coffee is usually processed by the dry method, therefore an expressive amount of husk is obtained every year. Some of the husk is used as organic fertilizer but, other applications are very limited, mainly because it is a bulky product. The presence of tannins and caffeine diminish acceptability and palatability of husk by animals. This review discuss degradation of caffeine by microorganisms, with special attention to bacterial, biological decaffeination of coffee husk and pulp and its subsequent use on animal feeding. The known biochemical routes of caffeine degradation by microorganisms are initially discussed; problems concerning physiological effects in animals, focusing on the limitations imposed by caffeine as an antiphysiological component are raised; the use of microorganisms to decaffeinate coffee husk and pulp is discussed. The discussions offer a view on decreasing caffeine content of coffee husk and pulp, which would allow the use of larger amounts of these products in animal feeding, partially replacing traditional components such as cereal grains.
\end{abstract}

Key words: Pseudomonas, coffee husk, decaffeination

\section{DEGRADAÇÃO DE CAFEÍNA POR MICRORGANISMOS E O EMPREGO DA PALHA E POLPA DE CAFÉ DESCAFEINADOS NA ALIMENTAÇÃO ANIMAL}

\begin{abstract}
RESUMO: A palha e a polpa de café são subprodutos obtidos durante o processamento do café, após a colheita. A primeira é produzida quando o café é processado pela via seca, enquanto que a outra, pela via úmida. Como no Brasil predomina a produção de café pela primeira via, o volume de palha é enorme. Além do seu uso como adubo orgânico, pouco tem sido a utilização da palha para outras finalidades, devido principalmente ao volume que ela ocupa. Particularmente à sua utilização na formulação de rações para animais, a presença de taninos e cafeína diminuem sua aceitação e palatabilidade. Nesta revisão discute-se a degradação de cafeína por microrganismos, particularmente bactérias, com vistas na sua utilização para descafeinar a palha e polpa de café para uso na alimentação animal. Inicialmente comenta-se sobre as rotas bioquímicas da degradação de cafeína por microrganismos. Na segunda parte da revisão são levantados os problemas referentes aos efeitos fisiológicos da cafeína em animais, limitando seu uso na composição de rações. A terceira parte da revisão aborda a questão da possibilidade do uso de microrganismos para diminuir o teor do alcalóide na palha e polpa de café, aumentando a aceitação pelos animais, logo, permitindo sua maior adição em rações em substituição aos cereais.

Palavras chave: Pseudomonas, palha de café, descafeinação
\end{abstract}

\section{INTRODUCTION}

The purine alkaloid caffeine (1,3,7trimethylxanthine) is found in more than sixty plant species, with significant levels in coffee beans, tea, cocoa, etc (Mazzafera, 1991; Suzuki et al., 1992; Sylvain, 1967). Other two important alkaloids of the xanthine derivative group are theobromine (3,7-dimethylxanthine) and theophylline (1,3- dimethylxanthine).

The popularity of coffee beverage is based on the stimulant effect of caffeine. Because of this pharmacological effect, caffeine has long been added to medical formulations to compensate the depressive effects of other drugs (James, 1991; Mazzafera, 1991). Caffeine is also a component of several cola drinks. The pure alkaloid commodity obtained as a by-product of coffee decaffeination, constitutes a valuable, since the addition of caffeine in cola drinks is responsible for almost $70 \%$ of the world's pure caffeine trading (Mazzafera, 1991). Although structurally very similar to caffeine, theophylline and theobromine have different physiological effects and, therefore, pharmaceutical applications. Theophylline is used as a bronchial dilator and to treat apnea, whereas theobromine has diuretic properties (Asano et al., 1993; Mingoia, 1967). 
In 1945, the USA produced 328 tons of caffeine, the price varying from US\$ 8.27 to US\$ 15.43 per kilogram (Sivetz, 1979). Between 1985 and 1987, 70 pharmaceutical and food companies operating in Brazil imported US\$ 3.6 million worth of caffeine, $66 \%$ of that from German companies, as coffee decaffeination byproduct (Mazzafera, 1991).

Most literature reports on caffeine are related to medical sciences, because of its physiological effect on animals. Since the first evidence of caffeine's action on the central nervous system, an increasing number of studies were carried out relating caffeine with several physiological effects and functions such as contractility of muscle tissue of heart and blood vessels, autonomic nervous system activity, renal function, gastrointestinal and respiratory systems, skeletal muscles, energy metabolism, neurotransmitters, neuroendocrine effects, etc. (Timson, 1975; James, 1991).

Caffeine is a competitive antagonist of adenosine receptors, what explains most of its physiological effects on the nervous system of animals (Stiles, 1992). Adenosine acts as a depressant, and being similar to the caffeine molecule, it can be replaced by the alkaloid. Therefore, the action of caffeine as a drug result from indirect effect, what and may explain why several studies show that caffeine ingestion can restore performance but not enhance it.

In humans and other animals, caffeine is first degraded to either paraxanthine (1,7-dimethylxanthine), theobromine or theophylline. The demethylation process is carried out by cytochrome P450 (Elias, 1986; James, 1991; Berthou et al., 1992). After a short period of caffeine ingestion, these dimethylxanthines can be detected in the urine. However, they can also be further demethylated to xanthine, and catabolised by the uric acid route. Alternatively, the methylxanthines produced during the catabolic pathway can be oxidized to the corresponding methyluric acids (Berthou et al., 1992).

\section{Caffeine and microorganisms: Metabolism and production of caffeine derivatives}

Through inhibition of DNA repair in bacteria it has been shown that caffeine can be mutagenic (Grigg, 1972; Kihlman, 1974). Caffeine at $0.1 \%$ concentration also reversibly inhibits protein synthesis in bacteria and yeast. This effect is post translational since caffeine does not affect RNA translation (Putrament et al., 1972).

Although high concentrations are required for bactericide action, caffeine is regarded as toxic for bacteria. However, some microorganisms have the ability to grow in the presence of caffeine and survival would be related to their capacity to degrade the alkaloid (Sundar-Raj \& Dhala, 1965). Actually, it is not rare to find bacterial strains resistant to caffeine (Woolfolk,1975).

Several studies were carried out to investigate the use of purines, including caffeine, as a source of energy for microorganism growth (Mazzafera et al., 1994;
Middelhoven \& Bakker, 1982; Schwimmer et al., 1971; Woolfolk, 1975; Woolfolk \& Downard, 1977). A comprehensive review on purine utilization by microorganisms was published by Vogels \& van der Drift (1976). Although fungi growing on caffeine have been isolated, most of the studies were done with bacteria isolated from soil, mainly those belonging to the Pseudomonads group, with particular attention to Pseudomonas putida (Burr \& Caesar, 1985).

Dickstein et al. (1957) and Bergmann et al. (1964) studied the degradation of 3-monomethylxanthine mediated by dehydrogenase activity in Pseudomonas fluorescens. They did not find activity with 1-monomethylxanthine as substrate. However, Woolfolk (1975) used a $P$. fluorescens strain with ability to grow on caffeine to demonstrate dehydrogenase activity against both monomethylxanthines. A was hydrolytic enzyme degraded caffeine, with the methyl groups being removed by sequential hydrolysis suggested. Methanol and xanthine were the final reaction products, and indications were that methanol was further oxidized to $\mathrm{CO}_{2}$.

Blecher \& Lingens (1977) studied degradation of caffeine by $P$. putida strains isolated from soil. They identified 14 catabolites: Theobromine, paraxanthine, 7-monomethylxanthine, xanthine, 3,7-dimethyluric acid, 1,7-dimethyluric acid, 7-methyluric acid, uric acid, allantoin, allantoic acid, ureidoglicolic acid, glioxilic acid, urea and formaldehyde.

Middlhoven \& Lommen (1984) studied degradation of caffeine as influenced by oxygen. They concluded that the first enzymatic steps in caffeine degradation in a $P$. putida strain were the successive removal of the three methyl groups, probably mediated by mono-oxygenases. However, they failed to demonstrate the mono-oxygenase activities.

Enzymological aspects of caffeine degradation by Pseudomonas putida were reported by Hohnloser et al. (1980) in detail. Using NADPH as cofactor in enzyme assays, they observed that only theobromine was formed from caffeine, but when they used paraxanthine, theobromine or 7-monomethylxanthine, they did not detect any activity. The authors suggested that there was only a single enzymatic system responsible for the sequential demethylation of caffeine. Regarding the lack of activity against theobromine and other substrates, they also suggested that although not detected in vitro, enzymatic degradation might occur in vivo but at very low rates. It was also argued that the slow and poor growth of the bacteria on caffeine as the sole source of carbon was due to a limiting demethylation of caffeine as well as other methylxanthines.

A limiting demethylation rate of caffeine was observed by Mazzafera et al. (1994) in a Serratia marcescens strain isolated from soil collected under coffee trees. By cultivating the bacteria on different substrates as the sole source of carbon and nitrogen, 
they could establish that caffeine was degraded to paraxanthine and/or theobromine, and subsequently to 7-monomethylxanthine and xanthine.

Sauer (1982) obtained indications that caffeine in yeast was degraded by cytochrome P-450, suggesting that the catabolic pathway might be similar to animals. In humans, several cytochrome P-450 isoforms are responsible for caffeine degradation (Berthou et al., 1992). However, data obtained by Schwimmer et al. (1971), who studied the degradation of caffeine to theophylline in fungi, and Blecher \& Lingens (1977), who studied degradation of caffeine to theobromine in bacteria, do not indicate participation of P-450 on caffeine degradation mechanism.

Gluck \& Lingens (1987) by P. putida mutants obtained a mixture of theobromine and paraxanthine as degradation products of caffeine. These results support inferences of Blecher \& Lingens (1977), who suggested that caffeine can be degraded either via theobromine or via paraxanthine. Similar conclusion was reached by Mazzafera et al. (1994) with S. marcescens.

Most studies on caffeine degradation by Pseudomonas use bacterial strains obtained through a procedure known as enrichment. Caffeine was added to the soil (Woolfolk, 1975) or culture medium (Blecher \& Lingens, 1977; Hohnloser et al., 1980; Middlhoven \& Lommen, 1984) to induce the appearance of mutants. In the case of soil enrichment, caffeine was mixed to the soil and incubated for several months. In the second case, using artificial media, caffeine was added in low concentrations and the bacteria subcultured several times until mutants were obtained. After that, bacteria were maintained in media containing caffeine as the sole source of carbon. Gluck \& Lingens (1987) isolated a $P$. putida strain by culturing the bacteria with $2.0 \%$ caffeine as the sole source of carbon and nitrogen. Blecher \& Lingens (1977) added caffeine up to $5.0 \%$ in the culture media. Middelhoven \& Bakker (1982) grew the strain C32024 of $P$. putida at $20 \mathrm{~g} \mathrm{~L}^{-1}$ of caffeine. However, Mazzafera et al. (1994) and Yamaoka-Yano \& Mazzafera (1998) used a different approach, and colledcted mutants in soil samples taken under coffee plants. Water was added to the soil samples and after shaking for a few hours, aliquots were plated in solid medium containing caffeine as the sole source of carbon and nitrogen. In the first case, they isolated a S. marcescens strain (Mazzafera et al., 1994) and in the second (YamaokaYano \& Mazzafera, 1998), several P. putida strains and other bacteria.

A strain of $P$. putida isolated by Yamaoka-Yano \& Mazzafera (1998) showed an impressive ability to grow in high concentrations of caffeine. Growth was observed at $25 \mathrm{~g} \mathrm{~L}^{-1}$ in liquid medium and at $50 \mathrm{~g} \mathrm{~L}^{-1}$ in solid medium. The direct isolation from the soil without any enrichment is a strong indication that because of competition for organic nutrients, bacteria growing in soil under coffee plants have developed mechanisms to degrade the caffeine released by the plants (leaves, fruits and litter). In other words, there was a natural enrichment.

Yamaoka-Yano \& Mazzafera (1999) studied the caffeine degradation pathway in this $P$. putida strain, and in agreement with results previously obtained by Blecher \& Lingens (1987), suggested the degradation pathway showed in Figure 1. Yamaoka-Yano \& Mazzafera (1999) also purified a xanthine oxidase, which is responsible for the conversion of methylxanthines to their respective uric acids. Attempts to purify the demethylase involved in the first step of caffeine degradation (Figure 1) were not successful (Yamaoka-Yano \& Mazzafera ${ }^{1}$ ). The activity was labile in partially purified extracts. The enzyme was NADH or NADPH - dependent producing theobromine and paraxanthine from caffeine. Activity was higher for paraxanthine, as observed in previous studies (YamaokaYano \& Mazzafera, 1998). It was also observed that caffeine demethylase was excreted in the culture medium. Addition of $\mathrm{Zn}$ to the reaction mixture inhibited caffeine degradation through theobromine, but not paraxanthine. Optimal activity was obtained in temperatures between 20 and $30^{\circ} \mathrm{C}$, and at pH 7.0. Since analysis of the liquid medium by SDS-PAGE revealed the presence of few proteins, proteins from two liters of culture medium were concentrated by $\left(\mathrm{NH}_{4}\right)_{2} \mathrm{SO}_{4}$ precipitation, desalted by dialysis and loaded on to an anionic exchange column (Mono Q). Demethylase activity was detected as a single peak eluted by a $\mathrm{NaCl}$ gradient, but both theobromine and paraxanthine were detected as products in the reaction mixture. Although several methodologies were tried in order to preserve activity, the enzyme was very labile, losing activity rapidly.

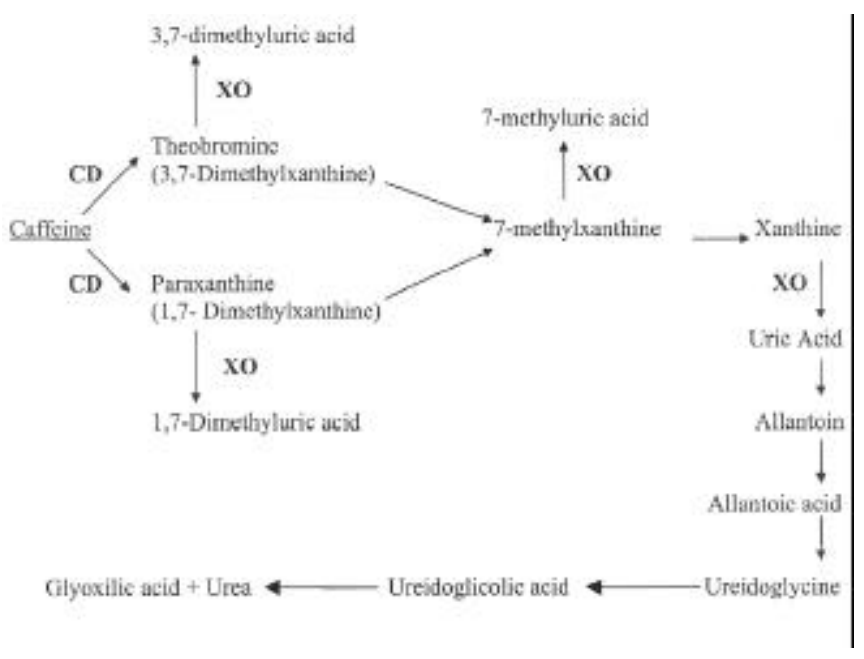

Figure 1 - Caffeine degradation pathway in Pseudomonas putida strain L, isolated by Yamaoka-Yano \& Mazzafera (1999). $\mathrm{XO}=$ Activity of Xanthine oxidase, $\mathrm{CD}=$ Activity of caffeine demethylase. 
Blecher \& Lingens (1977) and Gluck \& Lingens (1987) isolated $P$. putida mutants with the ability to degrade caffeine and attempted to block its degradation in order to produce caffeine derivatives for commercial application. In contrast to these authors, Asano et al. (1993) were successful in isolating a $P$. putida strain where the route of caffeine degradation could be blocked by addition of $\mathrm{Zn}$ to the culture medium, accumulating theobromine. This dimethylxanthine was excreted in the medium, and precipitated at the bottom of the flask because of its low solubility. This was the first time that a caffeine derivative was selectively produced using a bacteria.

\section{Use of coffee husk and pulp for animal feeding}

Coffee fruits can be processed by either wet or dry processing methods. In the majority of Brazilian coffee farms, fruits are dried naturally (sun-dried) or artificially (in furnaces). To obtain the seeds (beans), the exocarp, mesocarp and endocarp of the dried cherry coffee have to be removed by hulling, originating the socalled husk. In the wet processing procedure the fruits are pulped, fermented, washed and sun or artificially dried; The pulping procedure removes the exocarp and most of the mesocarp, resulting in the so-called coffee pulp. Part of the mesocarp remains adhered to the endocarp, and is lost by fermentation and subsequent washing. The dried coffee in the wet processing procedure is called dry parchment coffee, because the endocarp (parchment) is not removed; hulling the dry parchment coffee originates what is called hulls. The parchment is very rich in cellulose, and compared to exocarp and endocarp, it does not contribute significantly to the total fruit weight. Therefore, husk and pulp are the main by-products of the coffee processing. Pulp undergoes intense microbial fermentation and certainly has remarkable chemical differences in comparison to husk, although some degree of fermentation may also occur natural drying. Exocarp, plus mesocarp and endocarp represent $60 \%$ of the dried fruitmass. Therefore, a considerable volume of husk is produced when coffee fruitis processed (Coste, 1959).

Most Brazilian coffee farms use the husk as organic fertilizer, broadcasting it through out coffee plantations soils. However, despite its good chemical composition in comparing to with other organic fertilizers, mainly regarding $\mathrm{N}$ and $\mathrm{K}$ contents, the husk has the inconvenience of being bulky, making storage, handling and soil incorporation a problem (Elías, 1987), only part of the produced husk is used as fertilizer. Also because of its bulky consistance, coffee husk is inappropriate as a source of caffeine for the pharmaceutical and soft drink companies (Bressani, 1987b).

It is estimated that 1.3 million tons of coffee pulp is produced every year in Central America alone, and although partially used for compost production and application in coffee plantations and nurseries, most of it is disposed (Porres et al., 1993). For every 2 tons of coffee processed by the wet procedure, 1 ton of pulp is produced (Roussos et at., 1995). For coffee husk, it is estimated that 0.18 ton is produced for each ton of coffee fruits (Adams \& Dougan, 1981). Estimates of pulp to husk production ratio in Brazil are unknown. In view of this enormous volume of pulp/husk produced every year and its limited use as fertilizer and in other applications, it is argued that inappropriate disposal of this product, in rivers for instance, may cause serious environmental pollution (Porres et al., 1993).

Several studies have been carried out on the use of coffee pulp as food for animal husbandry (Braham, 1987; Bressani, 1987b; Cabezas et al., 1987; Jarquín, 1987). These studies were conducted in countries where coffee is processed mainly by the wet, method what explains the lack of information on coffee husk.

Limitations for the use coffee pulp in animal feeding are connected to its high contents on tannins and caffeine (Bressani, 1987a; Clifford \& Ramirez-Martinez, 1991). However, coffee pulp contains proteins, carbohydrates and minerals that may favor its utilization in animal feeding. Tables 1 and 2 show the chemical composition of coffee pulp; little is known of the composition of coffee husk. Pandey \& Soccol (1998) reported (dry matter basis) the contents for carbohydrates $(57.8 \%)$, proteins $(9.2 \%)$, fat $(2 \%)$, caffeine $(1.3 \%)$, tannins (4.5\%) and pectins (12.4\%).

Tannins are known to confer astringency to foodstuffs and complex proteins, affecting food

Table 1 - Chemical composition of coffee pulp in different hydration states and fermentation ${ }^{1}$.

\begin{tabular}{|c|c|c|c|}
\hline \multirow[t]{2}{*}{ Component } & \multicolumn{2}{|c|}{ Fresh Dehydrated } & \multirow{2}{*}{$\begin{array}{l}\text { Naturally fermented } \\
\text { and dehydrated } \\
\end{array}$} \\
\hline & $-----\cdot$ & ------- & \\
\hline Water & 77.0 & 12.6 & 7.9 \\
\hline Dry matter & 23.3 & 87.4 & 92.1 \\
\hline Ether extract & 0.48 & 2.5 & 2.6 \\
\hline Fiber & 3.4 & 21.0 & 20.8 \\
\hline Prote in $(\mathrm{N} \times 6.25)$ & 2.1 & 11.2 & 10.7 \\
\hline Ash & 1.5 & 8.3 & 8.8 \\
\hline $\mathrm{N}$ free extract & 15.8 & 44.4 & 49.2 \\
\hline
\end{tabular}

'From Elías (1987).

Table 2 - Organic components and minerals of the coffee pulp ${ }^{1}$.

\begin{tabular}{|c|c|c|c|c|c|}
\hline & \multirow{2}{*}{$\begin{array}{c}\text { Dry matter } \\
---\% \text {--- }\end{array}$} & \multicolumn{4}{|c|}{ Mineral } \\
\hline & & -- mg & $\%--$ & $--p p$ & om -- \\
\hline Tannins & $1.80-8.56$ & Ash & 8.3 & $\mathrm{Zn}$ & 4 \\
\hline Pectins & 6.5 & $\mathrm{Ca}$ & 554 & $\mathrm{Cu}$ & 5 \\
\hline Reducing sugars & 12.4 & $\mathrm{P}$ & 116 & $\mathrm{Mn}$ & 6.25 \\
\hline eNon rducing sugars & 2.0 & $\mathrm{Fe}$ & 15 & B & 26 \\
\hline Caffeine & 1.3 & $\mathrm{Na}$ & 100 & & \\
\hline Chlorogenic acid & 2.6 & $\mathrm{~K}$ & 1765 & & \\
\hline Caffeic acid & 1.6 & $\mathrm{Mg}$ & trace & & \\
\hline
\end{tabular}

${ }^{1}$ From Elías (1987). 
digestibility and decreasing nitrogen utilization animals. Although caffeine presents a somewhat bitter taste, thereby affecting palatability, the main limitations of this alkaloid for animal feeding are related to its physiological effects on the central nervous system (Bressani, 1987a). Most published studies regarding the physiological effects of caffeine in animals were performed on rats and mice and a few studies were carried out on hamsters, monkeys and baboons (Würzner, 1988; Milon et al., 1988; James 1991). As a trend, these studies demonstrated that 1 to $20 \mathrm{mg}$ caffeine per $\mathrm{Kg}$ of feed caffeine improve some abilities related to performance and activity. No conclusive results on studies of alertness were obtained. Furthermore, it was shown that caffeine does not have carcinogenic or teratogenic potential, even at unusually high, quite different dosages from normal human coffee consumption. Studies with larger animals were carried out only regarding the use of coffee husk or pulp as foodstuffs (Braham, 1987; Bressani, 1987a; Cabezas et al., 1987; Jarquín, 1987).

Among several foodstuffs, Aregheore (1998) reviewed the use of coffee pulp in animal feeding, concluding that its inclusion makes the food less palatable and interferes with nutrient availability and absorption in the gastrointestinal tract. Nitrogen availability is certainly affected by formation of protein complex by tannins.

The first studies with ruminants showed that cattle accepts coffee pulp as food only when supplemented with highly palatable feeds, forage, and protein concentrate (Cabezas et al., 1987). Cabezas et al. (1977), cited by Cabezas et al. (1987), incorporated $20 \%, 40 \%$ or $60 \%$ of sun-dried coffee pulp in rations as (15\% and protein) partial replacement of cottonseed meal and cottonseed hulls, enriched with a mixture of sugar cane molasses and minerals, and observed the intake and digestibility in calves. Protein was kept at $15 \%$. Although the digestibility of the organic matter increased from $51.2 \%$ ( $0 \%$ coffee pulp) to $54 \%$ (60\% coffee pulp) and the gross energy had not changed, the digestibility of protein decreased from $47 \%$ ( $0 \%$ coffee pulp) to $36.2 \%$ (60\% coffee pulp). The authors suggested that the observed increase was a consequence of the reduction of the daily intake, since it

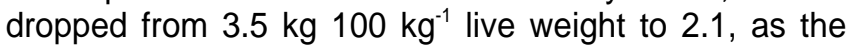
coffee pulp increased from 0 to $60 \%$ in the diet. Ingestion

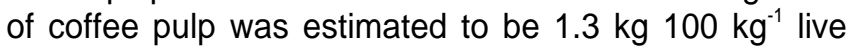
weight at the $60 \%$ coffee pulp level.

To investigate if these alterations resulted from tannins and caffeine contents, Cabezas et al. (1977), cited by Cabezas et al. (1987), included these compounds at the level reached when coffee pulp replaced cottonseed. Caffeine varied from $0.12 \%$ to $0.24 \%$, in combination or not with tannic acid. Tannic acid itself did not affect the performance of the calves. However, when caffeine was included, there was a significant decrease on daily weight gain and feed intake.
Vargas (1974), cited by Cabezas et al. (1987), also observed adverse effects of caffeine on the performance of young steers, when coffee was $40 \%$ in the ration. Cabezas et al. (1987) suggest that the cafeine effects in ruminants might be related to the increase of diuresis, which decreases nitrogen retention. Caffeine could also cause nervousness in animals, accelerating their basal metabolism.

In other studies with calves and dairy heifers, drastic reduction of feed intake and lower nitrogen referetion were observed when coffee pulp exceeded $20 \%$ in the rations, (Braham et al., 1973; Cabezas, 1974a; Cabezas, 1974b; Cabezas et al., 1987).

Very few studies were carried out on the use of coffee pulp on monogastric animals, feeding. Dried coffee pulp is accepted by pigs from 8 to $16 \%$ in the ration (Jarquín et al., 1974; 1977). At certain growth stages, lower weight gain was atributed to phenolics in the coffee pulp, since a study with decaffeinated coffee pulp showed that its addition to the ration did not improve the performance of piggeets in comparison to normal coffee pulp (Jarquín, 1987). Cunningham (1968) fed pigs with caffeine at the levels of $1.5 \mathrm{~g} \mathrm{~kg}^{-1}$ and observed that nitrogen retention increased $7.9 \%$, although a lower ration intake was detected. Therefore, considering the levels of coffee pulp used by Jarquín et al. $(1974,1977)$, it is probable that caffeine was not responsible for the diminished weight gain and feed conversion.

Coffee pulp also did not affect the growth of the fish Tilapia aurea (García \& Bayne, 1974). Compared to chicken manure, there was higher weight gain with a diet consisted of pellets containing $30 \%$ of coffee pulp plus wheat bran, ground corn, molasses, cottonseed oil meal, urea, and bone meal. Chicken manure was similar to a control diet that did not receive any additional supplementation.

On the other hand, dietary, coffee pulp severely decreased weight gain and caused $100 \%$ mortality in chicks (Bressani et al., 1973), which received diets containing $50 \%$ coffee pulp for 6 weeks. Bressani \& González (1978) added sodium metabisulfite to rations containing coffee pulp and observed that at $10 \%$ addition, performance was not altered. It seems that metabisulfite affect the levels of phenolics but not caffeine. Caffeine causes embryonic mortality in hens at levels of 0.05 and $0.1 \%$. Those fed with the highest level produced a $38.2 \%$ mortality rate (Ax et al., 1974). Caffeine given to males decreased semen output and sperm concentration dropped markedly.

From these studies it is not possible to draw a general conclusion regarding the use of coffee pulp for animal feeding. One has to keep in mind that not only caffeine is responsible for detrimental effects on animal growth, but also tannins seem to play an important role. However, in contrast to caffeine that can be used in a pure form in controlled diets, tannins differ in composition from 
plant to plant, and even tannic acid is not an useful guide. Therefore, for each animal type or category, the use of coffee pulp needs to be further investigated. Consideration should also be given to the use of coffee pulp or husks.

\section{Use of microrganisms to decaffeinate coffee husk and pulp}

In studies in which the addition of coffee pulp was made at relatively high amounts in animal diets, it was suggested that its success was related to the pulps processing method which would allow a decrease of caffeine and tannin contents by microorganisms degradation (Braham, 1987; Cabezas et al., 1987; Jarquín, 1987). Actually, Murillo (1987) showed a decrease of these substances in ensiled coffee husk.

Several studies have shown that coffee fruits are a rich source of microorganisms. Boccas et al. (1994) isolated 248 fungal cultures from coffee plants and soil collected from plantation areas. Roussos et al. (1995) isolated 272 strains of filamentous fungi from soil, fruits and leaves using a culture media containing coffee extract, coffee extract plus sucrose, and coffee pulp extract. The fungi strains with the highest ability to degrade caffeine were identified as Aspergillus and Penicillium. Yamaoka-Yano \& Mazzafera (1998) isolated more than 20 bacteria strains from soil collected under coffee plants, observing predominance of Pseudomonas sp., which was also the most efficient caffeine degrader. Silva et al. (2000) studied the diversity of microbial populations during the maturation and natural processing (sun-dried) of coffee fruits during two consecutive years. A total of 754 isolates of bacteria, yeast and fungi were obtained. Bacteria were the predominant microorganisms. The authors detected a large variation of microorganisms depending on the farm where the coffee was collected, the maturation stage, and the processing method, but no consistent pattern of variation was observed. Fermentative bacteria and yeast, cellulolytic bacteria, and pectinolytic bacteria, yeast and filamentous fungi were identified among 626 microorganisms.

This abundance and diversity of microbial species certainly explain why Porres et al. (1993) ensiled fresh coffee pulp with or without addition of sugar cane molasses and observed reduction of caffeine. A reduction in caffeine from $13-63 \%$ was observed, with the highest reduction in the treatment with $5 \%$ of molasses. The lowest reduction was observed in treatments in which the silage was pressed. This is a strong indication of the predominance of aerobic microorganisms in the coffee pulp.

Yamaoka-Yano \& Mazzafera (1996) used the same $P$. putida strain, used by Yamaoka-Yano \& Mazzafera (1998), to study coffee husk decaffeination. Different proportions of inoculum and husk were incubated during 30 days, resulting in a reduction of up to $80 \%$ of caffeine. At shorter incubation periods (9 days) a $40 \%$ reduction was observed.
Very few studies have been carried out to remove tannins from the coffee pulp. Menezes et al. (1994) showed that a strain of Lactobacillus plantarum was able to degrade up to $90 \%$ of the tannin present in coffee pulp. They used a simple fermentation procedure: Coffee pulp was homogenized with a $24 \mathrm{~h}$ inoculum and incubated for 8 days at $32^{\circ} \mathrm{C}$. Sucrose was also added at $1 \%$ to the mixture. The authors suggested that the detanninized product could be used for animal feeding. In another study, Menezes \& Romeiro (1996) used the pulp treated in the same way to feed rats, observing an increase of weight gain in comparison to the controls. They used up to $20 \%$ of the detanninized preparation in the diet.

\section{CONCLUSIONS}

Coffee husk or pulp can be used for feeding farm animals. Caffeine, which diminishes the palatability and acceptance of husk and pulp by animals, can be significantly reduced by microorganisms enabling partial substitution of traditional animal feed amendments, such as cereal grains. Although some animals tolerate high amounts of caffeine, others are more sensitive and could benefit by the microbial treatment. Despite this promising potential, little work has been done with microorganisms specially or specifically selected to degrade caffeine. In regard to tannins, which are also responsible for the low palatability of coffee husk/pulp, information is even more scarce. Since coffee husk and pulp are rich in other organic components, mainly carbohydrates and proteins present in the mesocarp of ripe fruits, the microbial process should be efficient and fast enough to avoid degradation of these compounds. Adaptation of microscale laboratory experiments to larger scale could show the viability of this alternative.

\section{REFERENCES}

ADAMS, M.R.; DOUGAN, J. Biological management of coffee processing. Tropical Science, v.123, p.178-196, 1981.

AREGHEORE, E.M. A review of implications of antiquality and toxic components in unconventional feedstuffs advocated for use in intensive animal production in Nigeria. Veterinary and Human Toxicology, v.40, p.35-39, 1998

ASANO, Y.; KOMEDA. T.; YAMADA. H. Microbial production of theobromine from caffeine. Bioscience Biotechnology Biochemistry, v.57, p.1286-1289, 1993.

AX, R.L.; LODGE, J.R.; BRAY, D.J. Increased embryonic loss in chickens from $0.05 \%$ dietary caffeine. Poultry Science, v.53, p.830-831, 1974.

BERGMANN, F.; UNGAR-WARON, H.; KWIETNY-GOVRIN H. Some specific reactions of the purine-oxidizing system of Pseudomonas aeruginosa. Biochimica et Biophysica Acta, v.79, p.512-522, 1964.

BERTHOU, F.; GUILLOIS, B.; RICHE, C.; DREANO, Y.; JACQZ-AIGRAIN, E.; BEAUNES, P.H. Interspecies variation in caffeine metabolism related to cytochrome P4501A enzymes. Xenobiotica, v.22, p.671-680, 1992.

BLECHER, R.; LINGENS, F.The metabolism of caffeine by a Pseudomonas putida strain. Hoppe-Seyler's Zeitschrift fuer Physiologische, v.358, p.807-817, 1977.

BOCCAS F.; ROUSSOS S.; GUTIERREZ M.; SERRANO L.; VINIEGRA G.G. production of pectinase from coffee pulp in solid-state fermentation system - selection of wild fungal isolate of high potency by a simple 3-step screening technique. Journal of Food Science and Technology-Mysore, v.31, p.22-26, 1994.

BRAHAM, J.E. Coffee pulp in other species. In: BRAHAN, J.E.; BRESSANI, R. (Ed.) Coffee pulp: composition, technology, and utilization. Guatemala City: Institute of Nutrition of Central America and Panama, 1987. p.51-54. 
BRAHAN, J.E.; JARQUÍN, R.; GONZÁLEZ, J.M.; BRESSANI, R. Pulpa y pergamino de café. III. Utilización de la pulpa de café en la alimentación de rumiantes. Turrialba, v.23, p.41-47, 1973.

BRESSANI, R. Antiphysiological factors in coffee pulp. In: BRAHAN, J.E.; BRESSANI, R. (Ed.) Coffee pulp: composition, technology, and utilization. Guatemala City: Institute of Nutrition of Central America and Panama, 1987a. p.83-88.

BRESSANI, R. Potential uses of coffee berry by-products. In: BRAHAN, J.E.; BRESSANI, R. (Ed.) Coffee pulp: composition, technology, and utilization. Guatemala City: Institute of Nutrition of Central America and Panama, 1987b. p.17-25.

BRESSANI, R.; ESTRADA, E.; ELÍAS, L.G.; JARQUÍN, R.; URRUTIA DE VALLE, L. Pulp y pergamino de café. IV. Efecto de la pulpa de café deshidratada en la dieta de ratas y pollos. Turrialba, v.23, p.403-409, 1973.

BRESSANI, R.; GONZÁLEZ, J.M. Evaluación de la pulpa de café como sustituto del maíz on raciones para pollos de carne. Archivos Latinoamericanos de Nutrición, v.28, p.208-211, 1978.

BURR, T.J.; CAESAR, A. Beneficial plant bacteria. CRC Critical Review in Plant Science, v.2, p.1-20, 1985.

CABEZAS, M.T.; GONZÁLEZ, J.M.; BRESSANI, R. Pulpa y pergamino de café. $\mathrm{V}$. Absorción y retención de notrógeno in terneros alimentados com raciones elaboradas con pulpa de café. Turrialba, v.24, p.90-94, 1974a.

CABEZAS, M.T.; MURILLO, B.; JARQUÍN, R.; GONZÁLEZ, J.M.; ESTRADA, E.; BRESSANI, R. Pulpa y pergamino de café. VI. Adapatación del ganado bovno a la pulpa de café. Turrialba, v.24, p.160-167, 1974b.

CABEZAS, M.T.; FLORES, A.; EGANA, J.I. Use of coffee pulp in ruminant feeding. In: BRAHAN, J.E.; BRESSANI, R. (Ed.) Coffee pulp: composition, technology, and utilization. Guatemala City: Institute of Nutrition of Central America and Panama, 1987. p.25-38.

CLIFFORD, M.N.; RAMIREZ-MENEZES, J.R. Tannins in wet-processed coffee beans and coffee pulp. Food Chemistry, v.40, p.35-42, 1991.

COSTE, R. Les caféiers et les cafés dans le monde. Paris: Éditions Larose. 1959. v.1, 372p

CUNNINGHAM, H.M. effects of caffeine on nitrogen retention, carcass composition, fat mobilization and the oxidation of $\mathrm{C}_{14}$-labeled body fat in pigs. Journal of Animal Science, v.27, p.242-430, 1968

DICKSTEIN, S.; BERGMANN, F.; HENIS, Y. Studies on uric acid and related compounds. IV.The specificity of bacterial xanthine oxidases. Journal of Biological Chemistry, v.224, p.67-77, 1957.

ELIAS, P.S. Current biological problems with coffee and caffeine. In: COLLOQUE INTERNATIONAL SUR LA CHIMIE DU CAFE. 12., Lome, 1985. Proceedings. Paris: Association Scientifique International du Café, 1986. p.93-112.

ELÍAS, L.G. Chemical composition of coffee-berry by-products. In: BRAHAN, J.E.; BRESSANI, R. (Ed.) Coffee pulp: composition, technology, and utilization. Guatemala City: Institute of Nutrition of Central America and Panama, 1987. p.11-16.

GARCIA, R.; BAYNE, D.R. Cultivo de Tilapia aurea (Steindachner) en corrales de $100 \mathrm{~m} 2$, alimentada artificialmente con gallinaza y un alimento preparado con $\mathbf{3 0} \%$ de pulpa de café. San Salvador: Ministerio de Agricultura y Ganadería, Dirección General de Recursos Naturales renovables, Servicio Piscícola, 1974.

GLUCK, M.; LINGENS, F. Studies on the microbial production of theobromine and heteroxanthine from caffeine. Applied Microbiology and Biotechnology, v.25, p.334-340, 198.

GRIGG, C.W. Effects of coumarin, pyronine Y, 6-9-dimethyl 2-methylthiopurine and caffeine on excision repair and recombination in Escherichia coli. Journal of General Microbiology, v.70, p.221-230, 1972.

HOHNLOSER, W.; OSWALD, B.; LINGENS, F. Enzymological aspects of caffeine demethylation and formaldehyde oxidation by Pseudomonas putida C1. Hoppe-Seyler's Zeitschrift fuer Physiologische, v.361, p.1763-1766, 1980.

JAMES, J.E. Caffeine and health. San Diego: Academic Press, 1991. 428p.

JARQUÍN, R.; ROSALES, F.A.; GONZÁLEZ, J.M.; BRAHAM, J.E.; BRESSANI, R. Pulpa y pergamino de café. IX. Uso de la pulpa de café en la alimentación de cerdos en la fase de crecimiento y acabado. Turrialba, v.24, p.41-46, 1974

JARQUÍN, R.; GOMES-BRENES, L.; BRESSANI, R. Efectos de los níveles proteínicos y de la pulpa de café en raciones para cerdos criolles. Turrialba, v.27, p.179-185, 1977.

JARQUÍN, R. Coffee pulp in swine feeding. In: BRAHAN, J.E.; BRESSANI, R. (Ed.) Coffee pulp: composition, technology, and utilization. Guatemala City: Institute of Nutrition of Central America and Panama, 1987. p.39-49.

KIHLMAN, B.A. Effects of caffeine on the genetic material. Mutation Research, v.26, p.53-71, 1974.

MAZZAFERA, P. A cafeína do café. Documentos do Instituto Agronômico de Campinas, v.25, p.1-22, 1991

MAZZAFERA, P.; OLSSON, O.; SANDBERG, G. Degradation of caffeine and related methylxanthines by Serratia marcescens isolated from soil under coffee cultivation. Microbial Ecology, v.31, p.199-207, 1994.
MENEZES, H.C.; SAMANN, F.S.; CLIFFORD, M.N.; ADAMS, M.R. The fermentation of fresh coffee pulp for use in animal feed. In: COLLOQUE INTERNATIONAL SUR LA CHIMIE DU CAFE E DU CACAO, 15., Montpellier, 1993. Proceedings. Paris: Association Scientifique International du Café, 1994. p.52-61.

MENEZES, H.C.; ROMEIRO, L.R. The incorporation of coffee pulp in animal feed - reduction of growth impairment by fermentation. Campinas: UNICAMP, Faculdade de Engenharia de Alimentos, 1996. 6p.

MIDDELHOVEN, W.J.; BAKKER, C.M. Degradation of caffeine by immobilized cells of $P$ seudomonas putida strain C3024. European Journal of Applied Microbiology and Biotechnology, v.15, p.214-217, 1982.

MIDDELHOVEN, W.J.; LOMMEN, A. Degradation of caffeine by Pseudomonas putida C3024. Antonie van Leeuwenhoek, v.50, p.298-300, 1984.

MILON, H.; GUIDOUX, R.; ANTONIOLI, J.A. Physiological effects of coffee and its components. In: CLARKE, R.J.; MACRAE, R. (Ed.) Coffee. London: Elsevier Applied Science, 1988. v.3, chap.4, p.81-124.

MINGOIA, Q. Excitantes do sistema nervoso central. In: MINGOIA, Q. (Ed.) Química farmacêutica. São Paulo: Melhoramentos, 1967. p.222-227.

MURILLO, B. Coffee-pulp silage. In: BRAHAN, J.E.; BRESSANI, R. (Ed.) Coffee pulp: composition, technology, and utilization. Guatemala City Institute of Nutrition of Central America and Panama, 1987. p.55-62.

PANDEY, A.; SOCCOL, C.R. Bioconversion of biomass: A case study of lignocellulosics bioconversions in solid state fermentation. Brazilian Archives of Biology and Technology, v.4, p.379-390, 1998.

PORRES, C.; ALVAREZ, D.; CALZADA, J. Caffeine reduction in coffee pulp through silage. Biotechnology Advances, v.11, p.519-523, 1993.

PUTRAMENT, A.; BARANOWSKA, H.; BILINSKI, T.; PRAZMO, W. On the specificity of caffeine effects. Molecular General Genetics, v.118, p.373-379, 1972.

ROUSSOS, S.; AQUIÁHUATL, M.A.; TREJO-HERNÁNDEZ, M.R.; PERRAUD, I.G.; FAVELA, E.; RAMAKRISHMA, M.; RAIMBAULT, M.; VINIEGRAGONZÁLEZ, G. Biotechnological management of coffee pulp-isolation, screening, characterization, selection of caffeine-degrading fungi and natural microflora present in coffee pulp and husk. Applied Microbiology and Biotechnology, v.42, p.756-762, 1995.

SAUER, M. Comparison of the cytochrome P-450 containing monooxigenases originating from two different yeasts. Developments in Biochemistry, v.23, p.452-457, 1982

SCHWIMMER, S.; KURTZMANN, R.H.; HEFTMANN, E. Caffeine metabolism by Penicillium roqueforti. Archives of Biochemistry and Biophysics, v.147, p.109-113, 1971.

SILVA, C.F.; SCWAN, R.F.; DIAS, E.S.; WHEALS, A.E. Microbial diversity during maturation and natural processing of coffee cheries of Coffea arabica in Brazil. International Journal of Food Microbiology, v.60, p.251-260, 2000.

SIVETZ, M. Coffee and its influence on consumers: physiological effects of coffee and caffeine. In: SIVETZ, M.; DESROSIER, N.W. (Ed.) Coffee technology. Westport: AVI Publishing, 1979. p.575-621.

STILES, G.L. Adenosine receptors. Journal of Biological Chemistry, v.267, p.6451-6454, 1992.

SUNDAR-RAJ, C.V.; DHALA, S. Effect os naturally occurring xanthines on bacteria. I.Antimicrobial action and potenting effect on antibiotic spectra. Applied Microbiology, v.13, p.432-436, 1965.

SUZUKI, T.; ASHIHARA, H.; WALLER, G.R. Purine and purine alkaloid metabolism in Camellia and Coffea plants. Phytochemistry, v.31, p.2575-2584, 1992.

SYLVAIN, P.G. El problema del contenido de cafeina en el cafe. Café, v.8, p.2-11, 1967

TIMSON, J. Theobromine and theophylline. Mutation Research, v.32, p.169-178, 1975.

VOGELS, G.D.; van der DRIFT, C. Degradation of purines and pyrimidines by microorganisms. Bacteriology Review, v.40, p.403-468, 1976.

WOOLFOLK, C.A. Metabolism of N-methylpurines by a Pseudomonas putida strain isolated by enrichment on caffeine as the sole source of carbon and nitrogen. Journal of Bacteriology, v.123, p.1088-1106, 1975.

WOOLFOLK, C.A.; DOWNARD, J.S. Distribution of xanthine oxidase and xanthine dehydrogenase specificity types among bacteria. Journal of Bacteriology, v.130, p.1175-1191, 1977.

WÜRZNER, H.P. Animal feeding studies with coffee. In: CLARKE, R.J.; MACRAE, R. (Ed.) Coffee. London: Elsevier Applied Science, 1988. chap. 7, p.171-194

YAMAOKA-YANO, D.M.; MAZZAFERA, P. Descafeinação da palha de café por bactérias. In: CONGRESSO BRASILEIRO DE PESQUISAS CAFEEIRAS, 22., Águas de Lindóia, 1996. Resumos. Rio de Janeiro: Ministério da Agricultura e Reforma Agrária, 1996. p.36-39.

YAMAOKA-YANO, D.M.; MAZZAFERA, P. Degradation of caffeine by Pseudomonas putida isolated from soil. Allelopathy Journal, v.5, p.23-34 1998.

YAMAOKA-YANO, D.M.; MAZZAFERA, P. Catabolic pathway of caffeine and purification of a xanthine oxidase responsible for methyluric acid production in Pseudomonas L. Revista de Microbiologia, v.30, p.70-78, 1999.

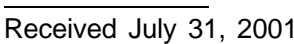

